\title{
THE
}

\section{Post-Menopausal Effects of Resistance Training on Muscle Damage and Mitochondria}

\author{
Thomas G. Manfredi \\ University of Rhode Island, tmanfredi@uri.edu \\ Michael Monteiro \\ University of Rhode Island \\ Linda S. Lamont \\ University of Rhode Island, lamont@uri.edu \\ Maria Singh \\ Mona Foldvari
}

See next page for additional authors

Follow this and additional works at: https://digitalcommons.uri.edu/kinesiology_facpubs

This is a pre-publication author manuscript of the final, published article.

Terms of Use

All rights reserved under copyright.

\section{Citation/Publisher Attribution}

Manfredi, T. G., Monteiro, M. A., Lamont, L. S., Singh, M. F., Foldvari, M., White, S., Cosmas, A. C., \& Urso, M. L. (2013). Post-Menopausal Effects of Resistance Training on Muscle Damage and Mitochondria. Journal of Strength and Conditioning Research, 27(2), 556-561. doi: 10.1519/JSC.0b013e318277a1e4 Available at: http://dx.doi.org/10.1519/JSC.0b013e318277a1e4 accepted for inclusion in Kinesiology Faculty Publications by an authorized administrator of DigitalCommons@URI. For more information, please contact digitalcommons-group@uri.edu. 


\section{Authors}

Thomas G. Manfredi, Michael Monteiro, Linda S. Lamont, Maria Singh, Mona Foldvari, Sebrina White, Arthur Cosmas, and Maria L. Urso 


\title{
Post-Menopausal Effects of Resistance Training on Muscle Damage and Mitochondria
}

\author{
Thomas G. Manfredi, Ph.D ${ }^{1}$, Michael Monteiro, MS ${ }^{1}$, Linda S. Lamont, Ph.D. ${ }^{1}$, Maria \\ Fiatarone Singh, M.D. ${ }^{2,3}$, Mona Foldvari, $\mathbf{M S}^{2}$, Sebrina White, $\mathbf{M S}^{1}$, Arthur Cosmas, Ph.D. ${ }^{1,4}$, \\ and Maria L. Urso, Ph.D. ${ }^{5}$ \\ ${ }^{1}$ Energy Metabolism Laboratory, Kinesiology Department, University of Rhode Island, Kingston, \\ Rhode Island, 02881-0810 \\ ${ }^{2}$ Nutrition, Exercise Physiology, and Sarcopenia Laboratory, Jean Mayer US Department of \\ Agriculture Human Research Center on Aging, Tufts University, Boston, 02111 \\ ${ }^{3}$ School of Exercise and Sport Science, University of Sydney, Lidcombe, New South Whales \\ 1825, Australia \\ ${ }^{4}$ Select Medical Sports Medicine and Outpatient Rehabilitation, West Hartford, CT. 06107 \\ ${ }^{5}$ Military Performance Division, US Army Research Institute of Environmental Medicine \\ (USARIEM), Natick, MA 01760
}

\begin{abstract}
The purpose of this study was to measure the effects of a 12 month, progressive resistance training intervention on muscle morphology and strength gains in postmenopausal women. Skeletal muscle biopsies were obtained from the vastus lateralis of five $(\mathrm{N}=5)$ independent community dwelling women, (mean age: $75.6 \pm 4.28 \mathrm{yrs}$; mean height: $163 \pm 5.34 \mathrm{~cm}$; mean weight: $72 \pm 17.5 \mathrm{~kg}$ ) before, six months and 12 months after progressive resistance training. Muscle strength (1-RM) was measured at the same time points. After six months of training morphological analysis revealed evidence of increased proteolysis and tissue repair, and rudimentary fiber development. The percent of $\mathrm{Z}$ bands with mild $\mathrm{Z}$ band disruption increased from $43.9 \%$ at baseline to $66.7 \%$ after six months of training $(\mathrm{p}<0.01)$. Mitochondrial volume also increased $(\%$ of mitochondria $=$ $0.86 \%$ at baseline, $1.19 \%$ at six months and $1.04 \%$ at 12 months, $\mathrm{p}<0.05)$ and there was a shift to larger sized mitochondria. The training did not result in statistically significant increases in muscle leg strength $(\mathrm{p}<0.18)$. It appears that mild $\mathrm{Z}$ band disruption acts as a precursor for increased protein synthesis and stimulates an increase in mitochondrial mass. Therefore, while a progressive resistance training program in this population did not increase muscle strength, it did demonstrate clinical applications that lend support to the importance of resistance training in older adults.
\end{abstract}

\section{Keywords \\ aging; exercise training; strength; muscle adaptation}

Please address correspondence to: Maria L. Urso, PhD, United States Army Research Institute of Environmental Medicine (USARIEM), 15 Kansas St., Building 42, Natick, MA 01760, Telephone 508-233-5619, Fax 508-233-4195, maria.urso@ us.army.mil. Publisher's Disclaimer: This is a PDF file of an unedited manuscript that has been accepted for publication. As a service to our customers we are providing this early version of the manuscript. The manuscript will undergo copyediting, typesetting, and review of the resulting proof before it is published in its final citable form. Please note that during the production process errors may be discovered which could affect the content, and all legal disclaimers that apply to the journal pertain.

Disclaimer: The opinions or assertions contained herein are the private views of the author(s) and are not to be construed as official or as reflecting the views of the Army or the Department of Defense. 


\section{INTRODUCTION}

There are many conspicuous effects of aging on skeletal muscle including a reduction in cross-sectional fiber area and an associated myofilament thinning (30). Fiber changes are accompanied by an infiltration of both fat and connective tissue and are attributed, at least in part, to decreases in estrogen production (19). Skeletal muscle also functions as a transmission site for oxidative stress through inflammatory cytokines that serve as mediators of muscle wasting (22).

Various pathological conditions increase the risk of metabolic dysregulation. Exercise has been found to attenuate metabolic abnormalities via improvements in muscle tissue mass and mitochondrial bioenergetics. Moderate endurance exercise and progressive resistance training, have been shown to be beneficial in patients with various pathologies $(3,14,21)$.

During menopause, endurance and resistance exercise have been shown to be effective in improving mitochondrial bioenergetics, metabolic dysregulation, and lean body mass (5). Mitochondrial bioenergetic effects include enhanced fat oxidation, accelerated turnover of stored triglycerides, improvements in insulin sensitivity and increased protein synthesis (16, 29). Resistance training has been shown to increase mass and strength in frail elders (6). It has been demonstrated that resistance training induces fiber damage accompanied by increases in strength, suggesting that muscle damage is a prerequisite to increasing strength in muscle of older adults and the frail elderly (25). There are no studies examining the longterm effects of moderate resistance training on skeletal muscle morphology in postmenopausal women. The aim of this study was to measure the effects of a 12 month, progressive resistance training intervention on muscle strength and morphology in postmenopausal women. We hypothesized that markers of fiber disarray and Z-band disruption would increase due to a training-induced increase in muscle repair. Similarly, we anticipated that long-term training would result in increased muscle strength and a shift toward larger mitochondria.

\section{METHODS}

\section{Experimental Approach to the Problem}

Post-menopausal women were recruited to participate in this study. Physiological measures of cardiovascular health, muscle strength, and vastus lateralis muscle biopsies were taken baseline and after six and 12 months of participating in a progressive resistance training program. Histological analysis was performed on muscle biopsy samples to determine the effects of the progressive resistance training program on skeletal muscle remodeling and adaptation.

\section{Subjects}

Five ( $\mathrm{N}=5$ ) independent community dwelling women, (mean age: $75.6 \pm 4.28 \mathrm{yrs}$; height: $163 \pm 5.34 \mathrm{~cm}$; weight: $72 \pm 17.5 \mathrm{~kg}$ ) participated in this study. Subjects taking any medications thought to interfere with exercise adaptation were excluded from this study (e.g. statins, diuretics). Skeletal muscle biopsies were taken from the vastus lateralis at baseline and after six and 12 months of participating in a progressive resistance training program. Resistance training was performed at the Jean Mayer USDA Human Nutrition Research Center on Aging (HNRC) at Tufts University, Boston, Massachusetts. Subjects were supervised during resistance training sessions. The study was performed in accordance with the Tufts University Human Investigation Review Committee. All subjects gave written informed consent prior to participation. 


\section{Physiologic Measures}

$\mathrm{VO}_{2}$ peak was measured on a motorized treadmill (Woodway, Waukesha, WI) by a graded exercise tolerance test with continuous analysis of expired gases using a face mask (Hans Rudolph, Kansas City, MO). Expired gases were analyzed by a Beckman LB-2 $\mathrm{CO}_{2}$ analyzer (Sensormedics, Schiller Park, IL) and an Applied Electrochemistry S-3A $\mathrm{O}_{2}$ analyzer (Applied Electrochemistry, Inc., Sunnyvale, CA). Analyzers were interfaced with a Zenith-PC minicomputer programmed for a 0.5 -minute output of minute ventilation, $\mathrm{CO}_{2}$ production, $\mathrm{VO}_{2}$ peak, and respiratory exchange ratio.

The treadmill speed was $0.1-3.0 \mathrm{mph}$, based on the habitual gait speed of each participant. The test was set initially at $80 \%$ of habitual gait speed, and then adjusted as needed. The first two minutes of the test were performed at $0 \%$ grade and the grade was increased by $2 \%$ every minute until the subject reached maximal effort. The highest oxygen consumption value during maximal effort was recorded as $\mathrm{VO}_{2}$ peak.

Dynamic strength was measured as the bilateral one repetition maximum (1-RM) obtained on the chest press, leg press, upper back, and hip abduction computer-interfaced pneumatic resistance machines (Keiser Sports Health Equipment Inc., Fresno, CA). The 1-RM was defined as the maximum load that could be moved one time only throughout the full range of motion using proper form. Beginning with minimal resistance, each new weight was lifted once until no more resistance could be applied. Incremental resistance was tailored for the subject to achieve the 1-RM in approximately 8 to 10 lifts. Baseline 1RM testing was repeated once by the same tester within the first week of the initial test. The best of the two baseline measures was used as the 1-RM.

\section{Exercise training intervention}

Training involved three, one hour sessions each week for 12 months. Exercise began with five minutes of static stretching followed by 15 minutes on a NuStep (Ann Abor, MI) or Stairmaster (Vancouver, WA), at $60 \pm 5 \%$ of maximum heart rate reserve or at a rating of perceived exertion of $8-9$ (20-point Borg scale). Following a brief walk and rehydration, the women engaged the first set of eight repetitions at $85 \%$ of 1-RM using Keiser equipment (Keiser Sports Health Equipment Inc., Fresno, CA). Exercises included chest press, leg press, upper back, and hip abduction. These muscle groups were chosen because of their importance in functional activities. Subjects rested for one minute between resistance exercises. A new baseline was established every two weeks using the results of the 1-RM strength test.

\section{Muscle Biopsies}

A muscle biopsy was taken from the lateral portion of the vastus lateralis $(\sim 20 \mathrm{~cm}$ above the knee) at baseline and after six and 12 months of training. Prior to the biopsy, the site was treated with 3-5cc of $1 \%$ lidocaine. A six mm incision was made in the skin and fascia to expose the muscle. A $5 \mathrm{~mm}$ biopsy needle (Popper and Sons, New Hyde Park, NY) was inserted into the incision and advanced through the fascia into the muscle with the cutting window closed. With suction applied, the cutting window was opened and closed three times, resulting in a sample of $\sim 75 \mathrm{mg}$. Samples were cleared of blood and connective tissue and stored at $-80^{\circ} \mathrm{C}$. Microscopy samples were fixed in $1 \%$ glutaraldehyde, $4 \%$ paraformaldehyde and embedded in LR white resin.

\section{Muscle examination}

Vastus lateralis biopsies embedded in LR white resin were sectioned longitudinally on an ultramicrotome, stained, and analyzed. A Phillips EM301 transmission electron microscope (Hillsboro, OR) interfaced with a computer equipped with an image-grabbing board (Data 
Translation, Marlboro, MA) was used. NIH Image software captured, stored, and calculated mitochondrial area. An investigator, blind to the condition and time point of each sample, analyzed ten fibers per subject using a 256 isotropic semicircular test point system. These fibers were used for stereological measurements of the percent of $Z$ bands that were disrupted (\%ZBD) (7).

Muscle fibers were also studied for degree of $\mathrm{Z}$ band disruption using the quantitative $\mathrm{Z}$ band disruption scale of Friden $(9,10)$. Each disrupted $Z$ band was scored from "0" to "4"; with " 0 " being no damage and " 4 " being the most extensive. Mitochondrial size distributions were calculated using mitochondrial area with each mitochondrion being placed into a size category: Size $1\left(0.010 u^{2}-0.030 u^{2}\right)$, Size $2\left(0.031 u^{2}-0.051 u^{2}\right)$, Size 3 $\left(0.052 \mathrm{u}^{2}-0.072 \mathrm{u}^{2}\right)$ and Size $4\left(0.073 \mathrm{u}^{2}-0.093 \mathrm{u}^{2}\right)$. Area measurements were taken for $\sim 500$ mitochondria (mean $=506$; range $=364-697$ ) at baseline, six and 12 months using established procedures $(24,25)$.

\section{Statistical Analysis}

Group means and standard deviations were determined for the morphometric measures and the statistics used included a repeated measures ANOVA and Pearson-Product Moment correlations. $\mathrm{P}<0.05$ was considered significant.

\section{RESULTS}

Patients

Peak oxygen consumption at baseline was $19.1 \pm 1.89 \mathrm{ml} / \mathrm{kg} / \mathrm{min}$ and remained within 1.4 $\mathrm{ml} / \mathrm{kg} / \mathrm{min}$ of baseline at six and 12 months. The training did not result in statistically significant increases in muscle leg strength $(\mathrm{p}<0.18$, Figure 1$)$.

\section{Muscle Examination}

Light microscopy of the baseline samples revealed fiber angulation suggestive of fiber atrophy. The presence of intrafasicular wedging, nuclear chains, satellite cell formation, and rudimentary fiber development was apparent after six and 12 months of training. Electron microscopy showed $\mathrm{Z}$ band disruption, fiber atrophy, sarcolemmal blebbing, retraction and separation from the endomysium, myoblast formation, aggregates of subsarcolemmal mitochondria, and alterations in the extracellular matrix. The electron micrographs in Figure 2 are skeletal muscle biopsies taken from the same subject at baseline, six, and 12 months of resistance training. Mild $Z$ band disruption $(Z)$ can be seen at six months. Figure 3 illustrates the percent of $Z$ bands disrupted (\%ZBD), a positive indicator of muscle overload (8). The magnitude of $Z$ band disruption after six months of training was significant $(p<0.05)$ and was categorized as mild (Figure 3; mean score $=0.899$; modified Friden scale).

Mean mitochondrial volume density increased 28\% after six months of training (Figure 4). When size distribution was used to classify mitochondria, increases in mitochondrial density were accompanied by an increase in larger sized mitochondria and a decrease in smaller sized mitochondria (Figure 5).

\section{DISCUSSION}

Sarcopenia is associated with atrophy, metabolic dysregulation (5) and a loss of strength and cross sectional area $(4,11,13)$. These changes are due in part to fiber atrophy, a loss of fast twitch fibers, and increased muscle fat infiltration. Clinical studies of independently living postmenopausal women report that one-third are overweight (19). These increases in wholebody fat mass are accompanied by decrements in physical activity, physical performance, 
and a higher frequency of disability. Exercise training can serve as a countermeasure to these physiological changes. Properly prescribed exercise can result in increased muscle strength, mass and bone density and reduced incidence of falls and fractures in postmenopausal women (26). We sought to determine the level of exercise needed to induce morphological changes that would render muscle metabolically fit while at the same time minimizing risk of injury due to excessive muscle damage and increasing strength gains.

Prior to training, we documented myofibrillar areas with sarcomeres in register despite scattered focal areas of fiber atrophy (characterized by mild $\mathrm{Z}$ band disruption). These may be morphological characteristics of the skeletal muscle of sedentary postmenopausal women. At six and 12 months of resistance training, more extensive areas of fiber atrophy and $\mathrm{Z}$ band disruption became evident. Roth et al. (23) quantified $\mathrm{Z}$ band damage in trained and control legs of young (20-30 years old) and older men (65 - 75 years old) after 9 weeks of heavy resistance strength training using isokinetic loading. They reported increases in muscle damage from $0-3 \%$ at baseline and 7 and $6 \%$ of the fibers in the treated vastus lateralis following training in the young and older men, respectively, with no differences between the old and young subjects. The authors note that the specificity of the workload must be considered, citing an earlier study by Manfredi et al. (20) that demonstrated greater damage in older adults when eccentric loads designed to create muscle damage was employed. The postmenopausal women who participated in this study experienced widespread, but mild, $\mathrm{Z}$ band disruption. These changes are suggestive of muscle tissue remodeling.

Although leg strength increased in all subjects, mean increases were not statistically significant (Figure 1). Indeed, in light of the small sample size, there is the potential that this is a type II error. However, based on the modest strength gains in each subject that appear to consistently level off after six months, it is possible that morphological changes are necessary for strength changes to occur in this aged population. These changes take place over a much slower time course than neurological changes that contribute to strength gains during the first few months of training. For example, sarcomere disruption observed at six months may indicate that $\mathrm{Z}$ band disruption is a morphological feature and a prerequisite to tissue remodeling. The relationship between muscle function and morphological change is supported by data from a previous study in which 10 weeks of resistance training in older adults (> 70 years) was accompanied by an increase in leg strength and percent $Z$ bands damaged (25).

Alternatively, the possibility exists that our strength training intervention was not rigorous enough for this population to experience strength gains. The machine-based exercises may not have provided an adequate stimulus for skeletal muscle adaptation. Similarly, participants only completed one bout of exercise for each muscle group. Additional sets of 8-10 repetitions may have promoted increased strength gains in this population. This is important to consider in the design of future studies.

This research group has previously shown evidence of a relationship between muscle function and morphological change. In a case-study using immunogold staining of quadriceps muscle IGF-1 receptors in elderly subjects, we determined that there was an increased receptor density with resistance training and these receptor changes were in concert with a heightened $\mathrm{Z}$ band disruption and appearance of central nuclei (27). This study also provided evidence that muscle remodeling due to exercise can reverse the down regulation of the IGF-1 system and that this may be an important mechanism for muscle anabolism in the older adult. 
Microscopic analysis revealed satellite cell formation, nuclear chains and fiber atrophy with myoblast development, aggregates of subsarcolemmal mitochondria and the maintenance of mitochondrial integrity at six and 12 months of training. In a similar study, Roth et al. (23) examined skeletal muscle satellite cell morphology in young and older men and women before and after heavy resistance strength training and reported greater satellite cells in the vastus lateralis of older men and women. Johnston et al. (17) suggest that the popular mitochondrial theory of aging that hypothesizes that the path leading to cell senescence includes damage to mitochondria can be counterbalanced in part with resistance training. Balakrishnan et al. (1) also used resistance training as a countermeasure toward increasing mitochondrial biogenesis. These data suggest that resistance training is effective in enhancing mitochondrial mass in older adults and is an important area for further investigation.

We found increases in mitochondrial density and mitochondrial size after six months of resistance training, an important countermeasure in view of previous studies of middle-aged and older adults reporting signs of atrophy associated with smaller mitochondrial size and a trend toward mitochondrial degeneration (2). Others indicate that mitochondrial ultrastructural integrity can be maintained with aging and that this is a favorable adaptation to exercise (15). Increases in skeletal muscle mitochondrial mass have been reported to accompany enhanced aerobic capacity $(12,18)$. Our laboratory found several weeks of combined resistance and aerobic exercise increased muscle mitochondrial area and the percentage of larger sized mitochondria in heart failure patients (24). Others reported an increase in mitochondrial sizes in type I and II fibers in young women after 18 weeks of resistance training (28). Importantly, this increase in mitochondrial mass per unit of muscle fiber provides the tissue with an environment that is conducive toward enhanced fatty acid oxidation and glucose flux $(5,28)$.

Results of this study indicate a long-term resistance training program has distinct advantages for older women. It provides positive changes that can retard the development of sarcopenia. The specific morphological changes become evident after six months of resistance training and they appear to be a prerequisite to muscle strength increases. Although no measurements of substrate oxidation were taken, an enhancement of mitochondrial mass and muscle strength implies improvements in bioenergetic mitochondrial capacity in the postmenopausal muscle.

\section{PRACTICAL APPLICATIONS}

This paper provides morphological data to support what is occurring within skeletal muscle tissue in older adults who participate in a progressive resistance training program.

These data are important as if one were to only focus on strength gains, progressive resistance training does not appear to be beneficial in older adults (based on a lack of significance in leg strength over the 12 month intervention). However, morphological data indicate that the muscle is undergoing favorable metabolic and structural adaptations that are essential in increasing muscle mass, overall physical function, and possibly, oxidative capacity. Therefore, while a progressive resistance training program in this population did not demonstrate statistically significant increases in muscle strength, it did demonstrate clinical applications that lend support to the importance of resistance training in older adults.

\section{Acknowledgments}

M. Monteiro was supported by a grant from the National Institutes of Health, Institute of General Medical Sciences, Bridges to the Future Grant R25 GM51780-02 awarded to the Kinesiology department (L.S. Lamont), University of Rhode Island. 


\section{Abbreviations}
IGF
insulin growth factor
vol\%ZBD
volume $\%$ Z-band disruption
ZBD
$\%$ disrupted $\mathrm{Z}$ bands relative to total $\mathrm{Z}$ bands

\section{References}

1. Balakrishnan VS, Rao M, Menon V, Gordon PL, Pilichowska M, Castaneda F, Castaneda-Sceppa C. Resistance training increases muscle mitochondrial biogenesis in patients with chronic kidney disease. Clin J Am Soc Nephrol. 2010; 5:996-1002. [PubMed: 20498251]

2. Bertoni-Freddari C, Fattoretti P, Caselli U, Giorgetti B, Albanelli S, Torelli F, Felzani G, Vecchiet J. A morphometric study on human muscle mitochondria in aging. Journal of the American Aging Association. 2002; 25:101-105.

3. Conraads VM, Beckers P, Bosmans J, De Clerck LS, Stevens WJ, Vrints CJ, Brutsaert DL. Combined endurance/resistance training reduces plasma TNF-alpha receptor levels in patients with chronic heart failure and coronary artery disease. Eur Heart J. 2002; 23:1854-1860. [PubMed: 12445534]

4. Dawson-Hughes B, Harris S. Regional changes in body composition by time of year in healthy postmenopausal women. Am J Clin Nutr. 1992; 56:307-313. [PubMed: 1636609]

5. DiPietro L. Exercise training and fat metabolism after menopause: implications for improved metabolic flexibility in aging. J Appl Physiol. 2010; 109:1569-1570. [PubMed: 20884835]

6. Fiatarone MA, O'Neill EF, Ryan ND, Clements KM, Solares GR, Nelson ME, Roberts SB, Kehayias JJ, Lipsitz LA, Evans WJ. Exercise training and nutritional supplementation for physical frailty in very elderly people. N Engl J Med. 1994; 330:1769-1775. [PubMed: 8190152]

7. Fielding RA, Manfredi TJ, Ding W, Fiatarone MA, Evans WJ, Cannon JG. Acute phase response in exercise. III. Neutrophil and IL-1 beta accumulation in skeletal muscle. Am J Physiol. 1993; 265:R166-R172. [PubMed: 8342683]

8. Fielding RA, Manfredi TJ, Ding WJ, Fiatarone MA, Evans WJ, Cannon JG. Acute-Phase Response in Exercise .3. Neutrophil and Il-1-Beta Accumulation in Skeletal-Muscle. American Journal of Physiology. 1993; 265:R166-R172. [PubMed: 8342683]

9. Friden J, Lieber RL. Structural and mechanical basis of exercise-induced muscle injury. Medicine and science in sports and exercise. 1992; 24:521-530. [PubMed: 1569848]

10. Friden J, Sjostrom M, Ekblom B. A morphological study of delayed muscle soreness. Experientia. 1981; 37:506-507. [PubMed: 7250326]

11. Frontera WR, Hughes VA, Fielding RA, Fiatarone MA, Evans WJ, Roubenoff R. Aging of skeletal muscle: a 12-yr longitudinal study. J Appl Physiol. 2000; 88:1321-1326. [PubMed: 10749826]

12. Holloszy JO. Biochemical adaptations in muscle. Effects of exercise on mitochondrial oxygen uptake and respiratory enzyme activity in skeletal muscle. J Biol Chem. 1967; 242:2278-2282. [PubMed: 4290225]

13. Hughes VA, Frontera WR, Wood M, Evans WJ, Dallal GE, Roubenoff R, Fiatarone Singh MA. Longitudinal muscle strength changes in older adults: influence of muscle mass, physical activity, and health. J Gerontol A Biol Sci Med Sci. 2001; 56:B209-B217. [PubMed: 11320101]

14. Innes KE, Selfe TK, Taylor AG. Menopause, the metabolic syndrome, and mind-body therapies. Menopause. 2008; 15:1005-1013. [PubMed: 18779682]

15. Ji LL, Leichtweis S. Exercise and oxidative stress: Sources of free radicals and their impact on antioxidant systems. Age. 1997; 20:91-106.

16. Johnson ML, Zarins Z, Fattor JA, Horning MA, Messonnier L, Lehman SL, Brooks GA. Twelve weeks of endurance training increases FFA mobilization and reesterification in postmenopausal women. J Appl Physiol. 2010; 109:1573-1581. [PubMed: 20651217]

17. Johnston AP, De Lisio M, Parise G. Resistance training, sarcopenia, and the mitochondrial theory of aging. Appl Physiol Nutr Metab. 2008; 33:191-199. [PubMed: 18347672] 
18. Kiessling KH, Pilstrom L, Karlsson J, Piehl K. Mitochondrial volume in skeletal muscle from young and old physically untrained and trained healthy men and from alcoholics. Clin Sci. 1973; 44:547-554. [PubMed: 4713662]

19. Lebrun CE, van der Schouw YT, de Jong FH, Grobbee DE, Lamberts SW. Fat mass rather than muscle strength is the major determinant of physical function and disability in postmenopausal women younger than 75 years of age. Menopause. 2006; 13:474-481. [PubMed: 16735945]

20. Manfredi TG, Fielding RA, O'Reilly KP, Meredith CN, Lee HY, Evans WJ. Plasma creatine kinase activity and exercise-induced muscle damage in older men. Med Sci Sports Exerc. 1991; 23:10281034. [PubMed: 1943622]

21. Marcora SM, Lemmey AB, Maddison PJ. Can progressive resistance training reverse cachexia in patients with rheumatoid arthritis? Results of a pilot study. J Rheumatol. 2005; 32:1031-1039. [PubMed: 15940763]

22. Moylan JS, Reid MB. Oxidative stress, chronic disease, and muscle wasting. Muscle Nerve. 2007; 35:411-429. [PubMed: 17266144]

23. Roth SM, Martel GF, Ivey FM, Lemmer JT, Tracy BL, Hurlbut DE, Metter EJ, Hurley BF, Rogers MA. Ultrastructural muscle damage in young vs. older men after high-volume, heavy-resistance strength training. J Appl Physiol. 1999; 86:1833-1840. [PubMed: 10368346]

24. Santoro C, Cosmas A, Forman D, Morghan A, Bairos L, Levesque S, Roubenoff R, Hennessey J, Lamont L, Manfredi T. Exercise training alters skeletal muscle mitochondrial morphometry in heart failure patients. J Cardiovasc Risk. 2002; 9:377-381. [PubMed: 12478208]

25. Singh MA, Ding W, Manfredi TJ, Solares GS, O'Neill EF, Clements KM, Ryan ND, Kehayias JJ, Fielding RA, Evans WJ. Insulin-like growth factor I in skeletal muscle after weight-lifting exercise in frail elders. Am J Physiol. 1999; 277:E135-E143. [PubMed: 10409137]

26. Sirola J, Rikkonen T. Muscle performance after the menopause. J Br Menopause Soc. 2005; 11:45-50. [PubMed: 15970014]

27. Urso ML, Singh MAF, Ding WJ, Evans WJ, Cosmas AC, Manfredi TG. Exercise training effects on skeletal muscle plasticity and IGF-1 receptors in frail elders. Age. 2005; 27:117-125.

28. Wang N, Hikida RS, Staron RS, Simoneau JA. Muscle fiber types of women after resistance training--quantitative ultrastructure and enzyme activity. Pflugers Arch. 1993; 424:494-502. [PubMed: 8255733]

29. Yarasheski KE. Managing sarcopenia with progressive resistance exercise training. J Nutr Health Aging. 2002; 6:349-356. [PubMed: 12474027]

30. Yu JG, Carlsson L, Thornell LE. Evidence for myofibril remodeling as opposed to myofibril damage in human muscles with DOMS: an ultrastructural and immunoelectron microscopic study. Histochem Cell Biol. 2004; 121:219-227. [PubMed: 14991331] 


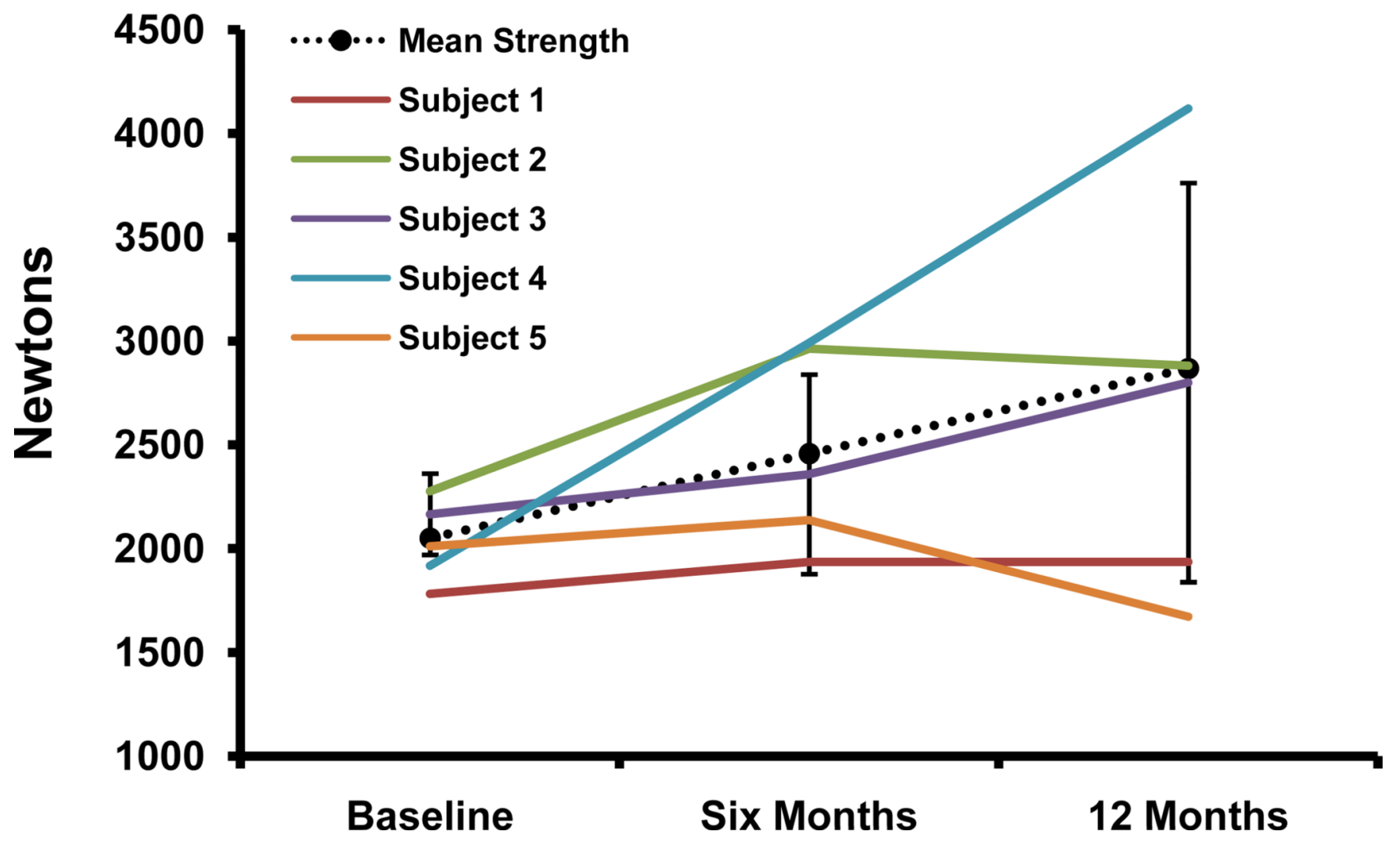

Figure 1.

Leg strength of the vastus lateralis at baseline and six and 12 months into the progressive resistance training. Solid lines illustrate individual subject strength scores (in Newtons). The dashed line represents mean strength data \pm SD. 


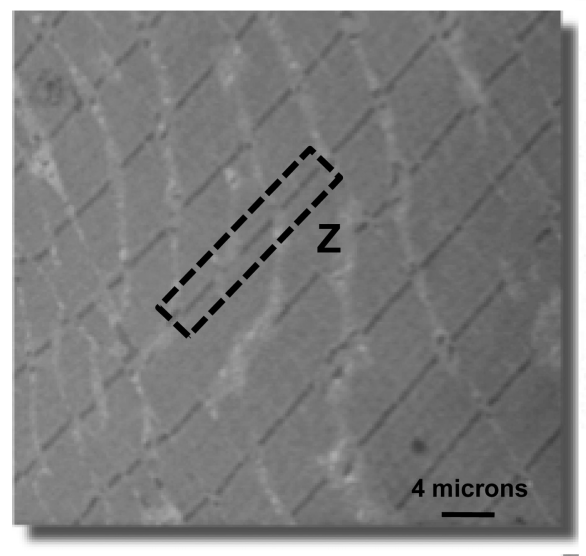

Baseline

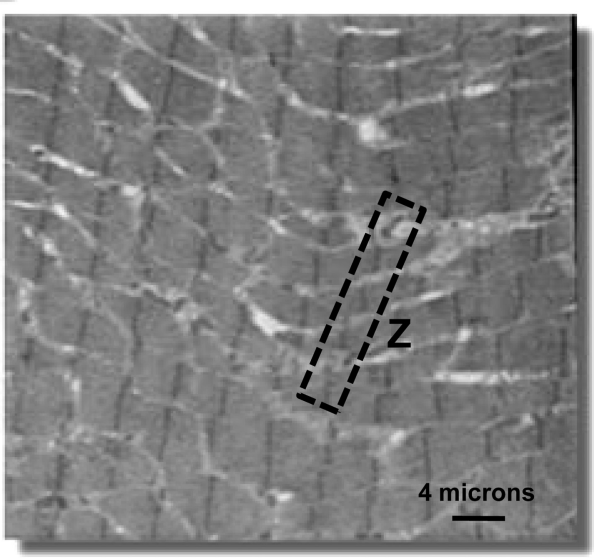

Six Months

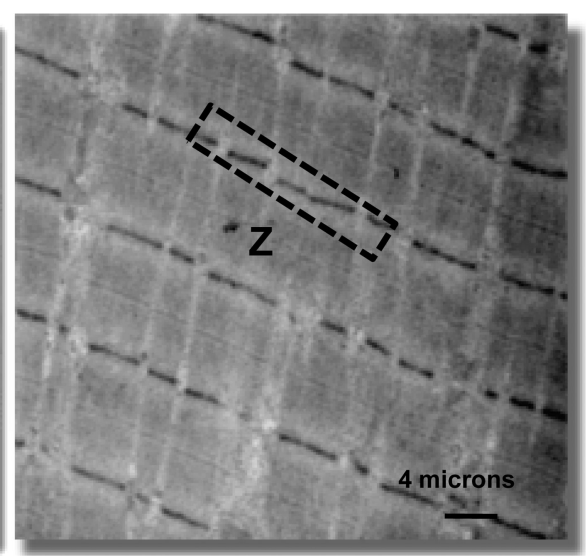

Twelve Months

Figure 2.

Electron Micrograph (EM) of skeletal muscle biopsies taken from the same subject at baseline and six and 12 months into the progressive resistance training. Note the greater degree of $\mathrm{Z}$ band disruption after six months of exercise training. 


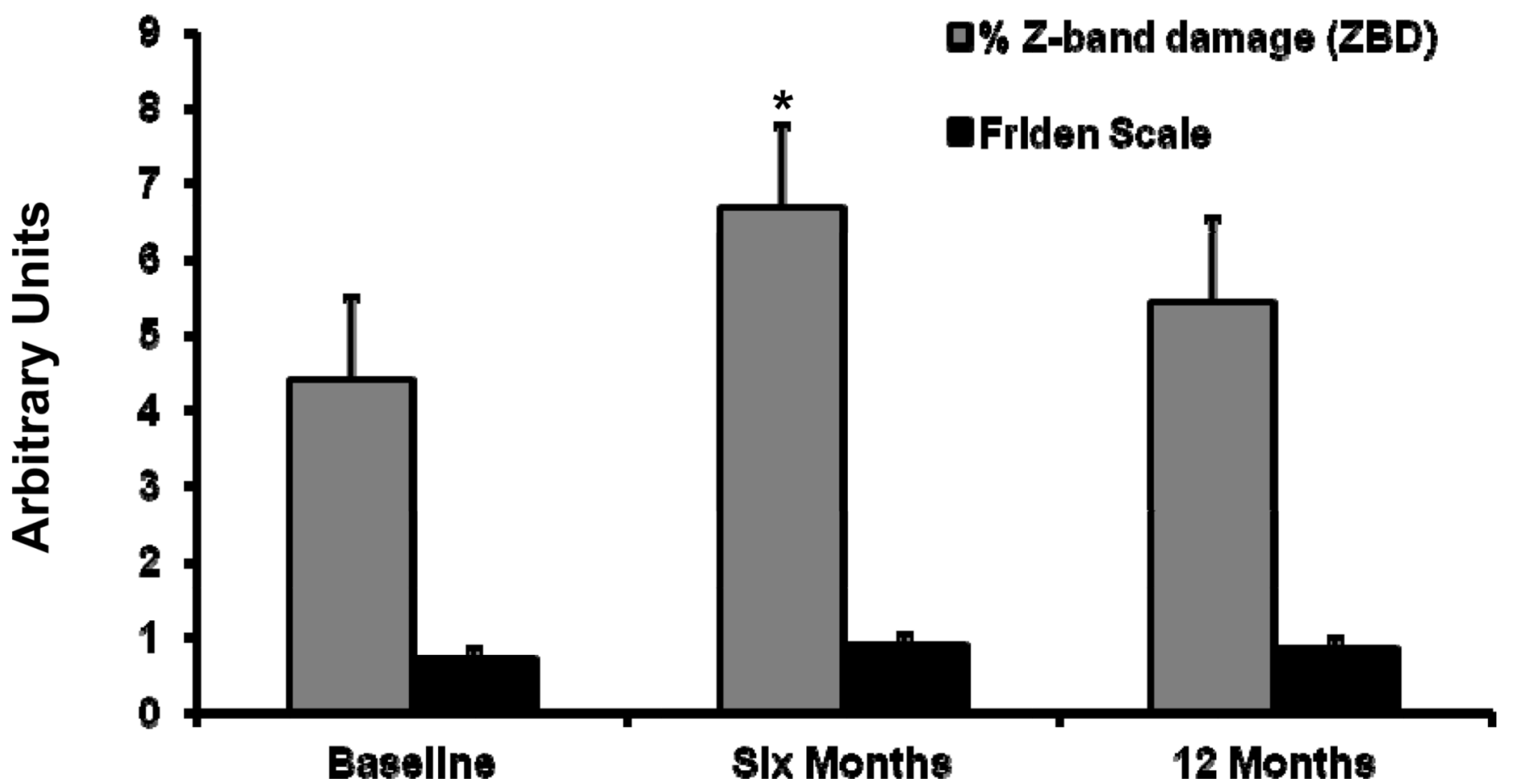

Figure 3.

Effect of training on markers of muscle $\mathrm{Z}$ band disruption $(\mathrm{ZBD}=$ Volume percent $\mathrm{Z}$-band disruption $\left.\left[1 \times 10^{-}\right]\right)$. $Z$ band disruption significantly increased at six months $(\mathrm{p}<0.05)$.

Volume percent data are means \pm SD. $*=p<0.05$ 


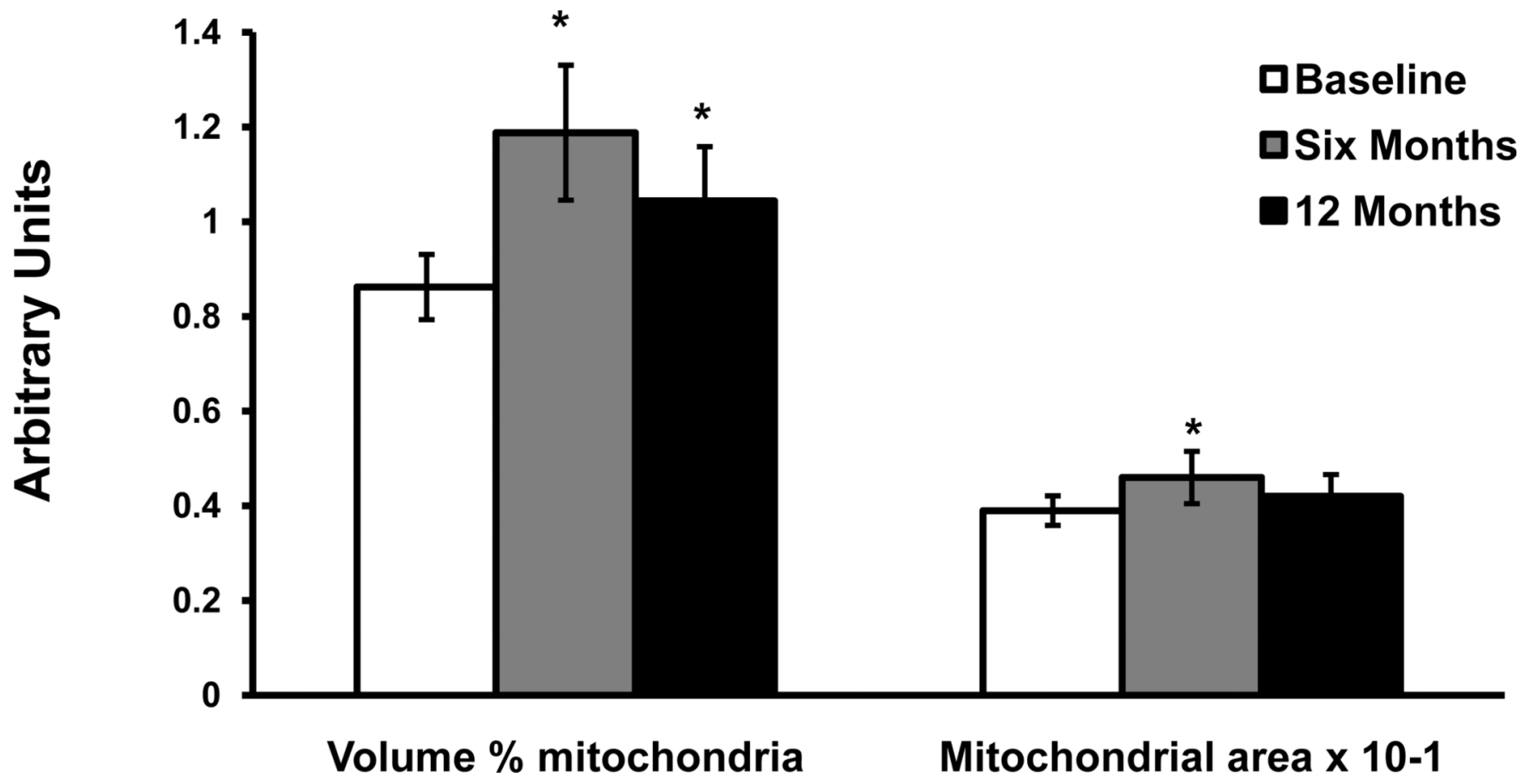

Figure 4.

Effect of exercise on mitochondrial volume density and area $\left(\mathrm{u}^{2} \times 10^{-1}\right)$. Data are means \pm SD. $*=p<0.05$ 
口Size 4 (0.073-0.093u2)

口Size 3 (0.052-0.072u2)

口Size 2 (0.031-0.051u2)

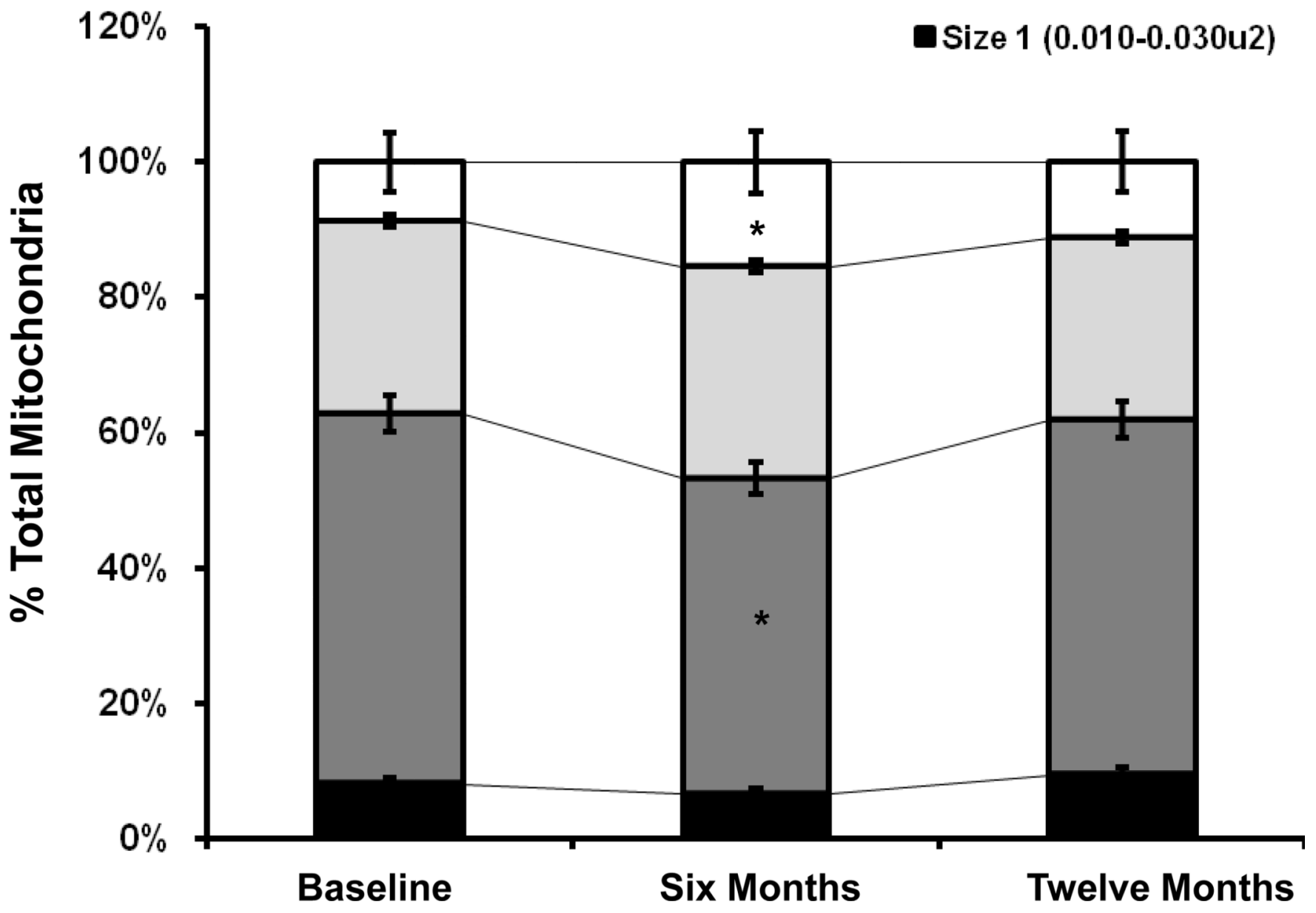

Figure 5.

Mitochondrial area size distributions at baseline, six and twelve months following training. At six months of training there was a significant increase in the percent of size 4 mitochondria $(\mathrm{p}<0.01)$ and a significant decrease in the percent of size 2 mitochondria $(\mathrm{p}<$ $0.05)$ compared to baseline. Data are means \pm SD. $*=p<0.05$ 